\title{
Interleukin-2 ved transplantat-mot-vert-sykdom
}

\author{
Interleukin-2 i lave doser øker \\ antall regulatoriske T-celler. Dette \\ kan ha betydning for pasienter \\ med kronisk transplantat-mot- \\ vert-sykdom
}

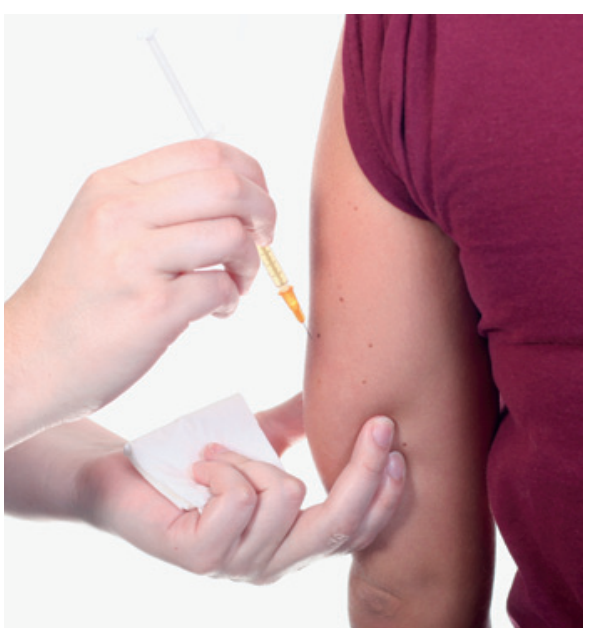

Illustrasjonsfoto Thinkstock
Dysfunksjon av regulatoriske T-celler (Treg-celler) er påvist ved flere inflammatoriske sykdommer, bl.a. kronisk transplantat-mot-vert-sykdom. Interleukin-2 er viktig for Treg-cellenes vekst, overlevelse og aktivitet. Dette er bakgrunnen for en fase 1-studie for å undersøke om interleukin-2 i lave doser kan øke antall Treg-celler og redusere symptomene på kronisk transplantat-motvert-sykdom (1).

28 av 29 pasienter med kronisk transplantat-mot-vert-sykdom som var refraktær overfor glukokortikoider, fullførte åtte ukers behandling med interleukin-2. Høyeste tolererte dose var $1 \cdot 10^{6} \mathrm{IU} / \mathrm{m}^{2} / \mathrm{dag}$. Det ble ikke observert tilbakefall eller sykdomsprogrediering hos noen pasienter. Behandlingen førte til økning i antall Treg-celler til over åtte ganger utgangsverdien, uten tilsvarende økning av konvensjonelle CD4positive T-celler. Det ble observert klinisk respons hos 12 av de 23 pasientene som kunne evalueres.

- Kronisk transplantat-mot-vert-sykdom er fortsatt et betydelig problem ved allogen stamcelletransplantasjon og er en viktig årsak til at behandlingsresultatene ikke er så gode som vi ønsker, sier Geir Tjønnfjord, som er professor og avdelingsleder ved Avdeling for blodsykdommer, Oslo universitetssykehus.

- $\AA$ øke antall CD4-positive Treg-celler ved bruk av interleukin-2 er en svært interessant tilnærming, sier Tjønnfjord. - Men observasjonstiden i denne studien er kort, og det er ikke avklart om behandlingen må fortsette på ubestemt tid. Det er også usikkert hvilke konsekvenser behandlingen kan ha for risiko for residiv av grunnsykdom og for infeksjoner, tilføyer Tjønnfjord.

\section{Merete Kile Holtermann \\ merete.holtermann@legeforeningen.no \\ Tidsskriftet \\ Litteratur \\ Koreth J, Matsuoka K, Kim HT et al. Interleukin-2 and regulatory $T$ cells in graft-versus-host disease. N Engl J Med 2011: 365: 2055-66.}

\section{Vedvarende hormonendringer etter vekttap}

\section{Vekttap fører til endringer i nivået av flere appetitt- og vektregulerende hormoner. Endringene vedvarer i minst ett år.}

I en ny prospektiv studie har forskere undersøkt hva som skjer med nivået av hormoner som regulerer kroppsvekt og appetitt etter vekttap (1). 50 pasienter med BMI 27-40 $\mathrm{kg} / \mathrm{m}^{2}$ ble inkludert og gjennomgikk et tiukers program for kostindusert vektreduksjon, etterfulgt av ett års oppfølging. Fastende og postprandiale hormonnivåer ble målt før start og etter ti og 62 uker.

Vekttap førte til signifikante endringer i nivåene for flere hormoner. Ett år etter vekttapet var det fortsatt forskjeller i hormonnivåene sammenliknet med verdier før vekttap for hormonene leptin, peptid YY, kolecystokinin, insulin, ghrelin, gastrisk inhibitorisk polypeptid (GIP) og pankreatisk polypeptid. Deltakerne hadde i gjennomsnitt en moderat vektøkning i denne perioden.

- Selv om de fleste endringene i enkelthormoner er beskrevet tidligere, er det nye her at mange hormoner er studert samtidig. Endringene i hormonnivå og appetitt etter vekttap vedvarte over tid. Dette er med på å forklare hvorfor det er så vanskelig å ved- likeholde en vektreduksjon, sier Kåre I. Birkeland, professor i endokrinologi ved Oslo universitetssykehus.

- De viktigste svakhetene ved undersøkelsen er at den er observasjonell og derfor vanskelig kan gi grunnlag for slutninger om årsak og virkning. Dessuten er hormonforandringene kun beskrevet hos dem som fullførte studien. Man kan derfor ikke vite om de hormonelle endringene var annerledes hos dem som ikke oppnådde det fastsatte målet for vektreduksjon, eller som valgte å avbryte studien, sier Birkeland.

\section{Merete Kile Holtermann}

merete.holtermann@legeforeningen.no Tidsskriftet

\footnotetext{
Litteratur

1. Sumithran P, Prendergast LA, Delbridge E et al. Long-term persistence of hormonal adaptations to weight loss. N Engl J Med 2011; 365: 1597-604.
}

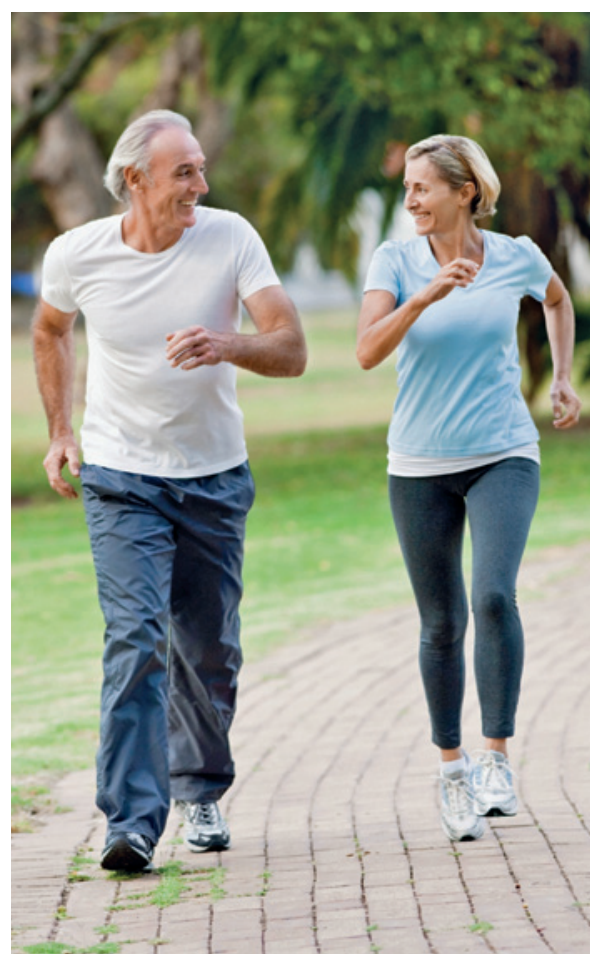

Illustrasjonsfoto Istockphoto 